\title{
Desiccation of Lake Chad as a cause of security instability in the Sahel region
}

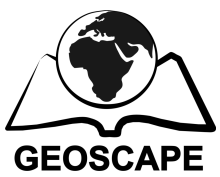

\author{
Kateřina Rudincová ${ }^{1 *}$ \\ ${ }^{1}$ Department of Geography, Faculty of Sciences, Humanities and Education, \\ Technical University of Liberec, Czech Republic \\ * Corresponding author: katerina.rudincova@tul.cz
}

\begin{abstract}
The Lake Chad basin is one of the most unstable regions in Africa. The lake itself has shrunk and nowadays it covers less than $10 \%$ of its area in 1960 . These environmental changes have wider geopolitical consequences in the whole region, which encompasses countries such as Nigeria, Niger, Chad and Cameroon. Therefore, it seems that environmental threats may act as the detonators for larger political conflict as well as for a struggle for land and may cause growing instability in affected countries. The region is fragile, owing to the fact that several terrorist and Islamist groups are operating there. The most serious threat in the Lake Chad basin is militant Islamist group Boko Haram, which is based in north eastern Nigeria, but it is also active in neighbouring countries. As a result of both ecological changes and security threats, people are losing their traditional sources of income from herding and it is likely that there will be large waves of migration from the area. The paper focuses on the environmental challenges in the Lake Chad basin and their effect on the security in the region. The main attention will be paid to the strategies and actions of militant terrorist groups such as Boko Haram that will be analysed in the wider regional geopolitical context.
\end{abstract}

Key words: Lake Chad, Boko Haram, Nigeria, terrorism, environmental issues

Highlights for public administration, management and planning:

- It is necessary to increasingly address the environmental causes of human insecurity in the region as precursors of the deprivation of living conditions and political unrest.

- Cooperation between the states in the Lake Chad Basin and international organizations is crucial in order to fight terrorism in northern Nigeria effectively.

Received: 17 Oct 2017 - Received in revised form: 22 Dec 2017 - Accepted: 22 Dec 2017

\section{Introduction}

Since 2009, Boko Haram has become well-known in Western media due to its violent attacks mainly in the northern part of Nigeria. Currently, it is able to carry out terrorist acts not only within the territory of Nigeria, but also in neighbouring countries. Formation of this movement has been put into the connection with a general Islamic revivalist movement as well as with the failure of the state in Nigeria. However, author of this text argues, that its operation in the northern Nigerian states such as Borno is enabled also by the environmental conditions. Desiccation of the Lake Chad has had an impact on human security in the region. Population has become more vulnerable due to these environmental changes and therefore, it became an easy target for Boko Haram's violent actions and in some respect, it even supported it. Many has been written about the origin of Boko Haram (e.g., Adesoji 2011; Agbiboa 2013b), their strategies (e.g., Agbiboa 2013a) and regional consequences (e.g., Thurston 2016). However, this article offers an alternative view on this organization from different perspective, relying to a large extent on analysis of environmental factors causing insurgencies and violence.

From the methodological point of view, this text is an intrinsic case study (Ženka \& Kofroň 2012). This approach has been adopted since 
"qualitative case study is an approach to research that facilitates exploration of a phenomenon within its context" (Baxter \& Jack 2008, p. 544). Therefore, the main aim of this text is to determine if the desiccation of Lake Chad affects the security issues in the analysed region. Moreover, the emergence of Boko Haram is studied in connection with the broader issues of terrorism and Islamic fundamentalism in Africa.

Concerning outline of this paper, the first part deals with the theoretic framework and evaluates the impact of the environmental changes on the conflict potential, applied on the case study of the Lake Chad Basin. It deals with the environmental and socio-economic issues in the Lake Chad basin and tries to evaluate possible causes of the emergence of Boko Haram in northern Nigeria. Second part of the article is dedicated to the analysis of formation of Boko Haram, its ideology and strategies. The final part of the text puts the Boko Haram operation into wider geopolitical regional context and evaluates its possible cooperation with other Islamist terrorist groups in the region.

\section{Causes of insecurity in northern Nigeria}

Recently, there have been vast literature published on the causality between climate change and violent conflict (e. g., Scheffran et al. 2012; Homer-Dixon 1994; Homer-Dixon \& Deligiannis 2009). On one hand, some authors argue, that climate change influences resource scarcities, which leads to a violent conflict (e.g., Burke et al. 2009). On the other, there are authors who argue, that climate change itself does not produce conflict, but it is the lack of adaptability of governments and their effectiveness which may lead to conflict over resources (e.g., Barnett \& Adger 2007; Salehyan 2008; Cook \& Bakker 2012).

Okpara et al. (2015) classify three key lineages between water and conflict: (i) decline of water quality may act as a source of the conflict; (ii) the importance of water for livelihoods creates a source of conflict, and (iii) inadequate water management affects potential for conflict. In the case of Lake Chad, particularly the second cause is observed (see Coe \& Foley 2001) which means that people are mostly deprived of their sources of livelihood caused by the desiccation of water sources in the region. As a consequence, they have become more vulnerable to various kinds of violence including Boko Haram attacks.

As the previous research suggests, the desiccation of water sources in sub-Saharan Africa and scarcity of water serve as environmental push elements causing migration of thousands of people (Lonergan 1998). Deteriorating security situation then makes it difficult for environmental NGOs to work effectively in order to stop water resources degradation (Slavíková et al. 2017). Moreover, environmental problems connected to drylands and scarcity of water resources may serve as causal factors of conflicts (Spiess 2005, p. 831). However, the scarcity of resources should not be understood as a single cause of the conflicts. Instead, it is important to deal with it only as it was one of the factors contributing to the emergence of multi-causal conflicts (Hagmann 2005).

Similarly, even though Boko Haram is a rigid Islamic movement, its emergence may not be seen only in connection with religious revivalism and religious ideology, but it also has to be studied and analysed in connection with the deprivation of living standards of local population in northern Nigeria caused to a certain extent by environmental factors. Jeffrey Seul (1999) suggests in his article entitled "Ours is the Way of God" that religion serves solely as an unifying and mobilising identity and it is not itself a source of conflicts. Therefore, we may understand the origin of Boko Haram in connection to deeply rooted economic, religious and environmental factors.

Currently, significant part of Sub-Saharan Africa contends with the environmental and ecological changes, which are manifested mainly by the desertification of the Sahel region. The Lake Chad desiccation, which is the most serious environmental threat in the region, has both natural as well as anthropogenic causes. Since 1960s, rainfall in the Chad basin has decreased significantly and at the same time, the usage of water for irrigation has increased in order to 
ensure income from agriculture. As a result, the area of Lake Chad itself has been reduced from around $25000 \mathrm{~km}^{2}$ in 1963 to around $1350 \mathrm{~km}^{2}$ in 2001 (Coe \& Foley 2001, p. 3349; Fig. 1). The desiccation of the lake has had a great impact on local population which has been to certain extent economically dependent on fishing and cattle herding (Onuoha 2008; Béné et al. 2003). Therefore, climate change have inflicted serious human security issues in this area causing the change of livelihood of about 750000 people
(Coe \& Foley 2001, p. 3349). Wolf et al. (2003) even identified Lake Chad among the lakes with the highest potential risk for socio-political stress. As a response to these changes in the Lake Chad basin, the UN Food and Agriculture Organization (FAO) called the deteriorating situation in this region an 'ecological catastrophe' and predicted the lake to disappear in the horizon of one century, which may have a devastating impact on population in Nigeria, Cameroon, Chad and Niger (Salkida 2012).

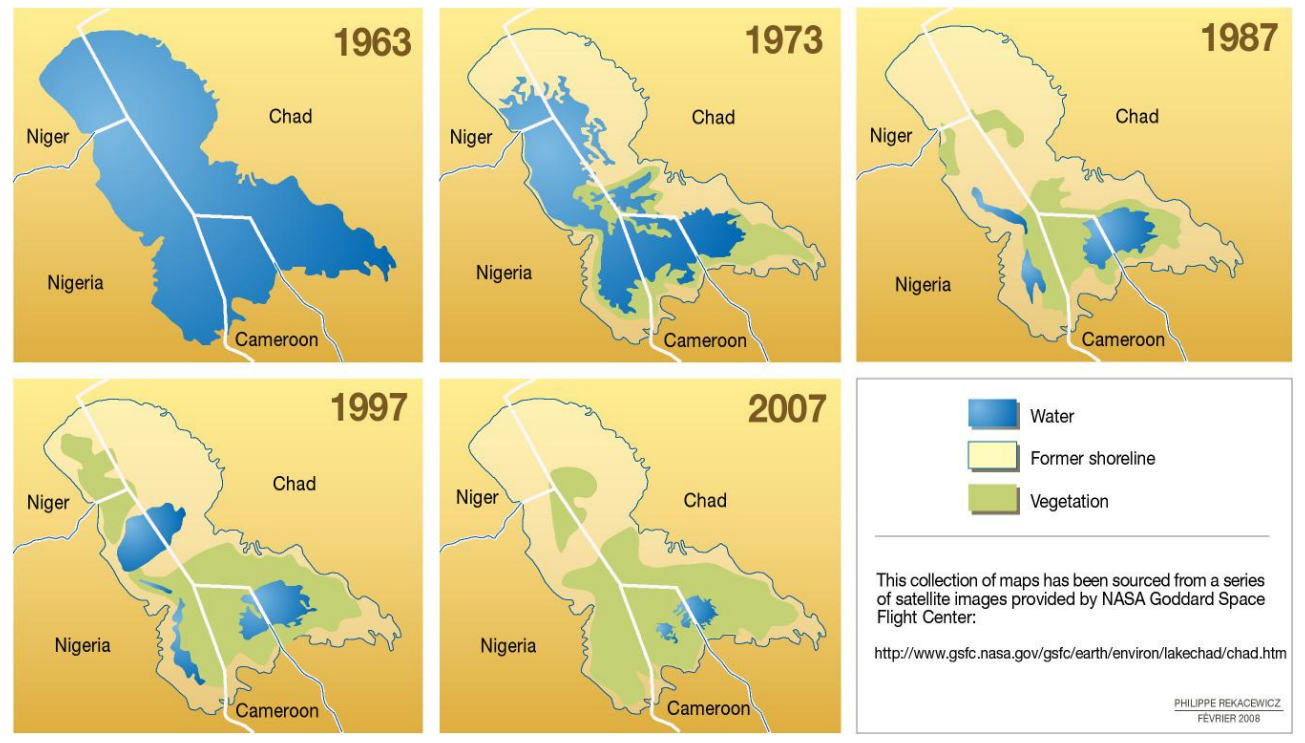

Fig. 1 - Desiccation of the Lake Chad between 1963 and 2007 (source: Rekacewicz 2008)

The worsening ecological conditions in Lake Chad basin have serious impact on the living conditions of local population. As Daniel Agbiboa (2013a; 2013b) suggests, therefore, the causes of Boko Haram's successful violent campaign in northern Nigeria may be explained by the relative deprivation theory. According to this approach, "violent actions flourish within a context of grievances caused by relative deprivation", which means the discrepancy between what people would like to have and what they actually have or they could get. The insurgencies originated in the northern part, which is the most socioeconomically deprived part of the country, since, in this environment, radical Islamic groups are able to challenge the state power and successfully promote their ideas.
According to Nigerian statistical office, the region of Northern Nigeria is the least developed. The literacy in Nigeria differs significantly in the southern and northern states of the country, with the lowest literacy rate in the Borno State in northern Nigeria which reaches only $14.5 \%$ (UNESCO 2012). Northern part of the country has to deal with the economic issues as well. For example, the unemployment rate reached even 42.6\% in the Zamfara state in 2012 (National Bureau of Statistics 2012). Unemployment is one of the most important factors which contribute negatively to the security in northern Nigeria. As Sope Elegbe, Research Director of the Nigerian Economic Summit Groups (NESG) stated: "The increasing poverty in Nigeria is accompanied by increasing unemployment. [...] Mix this situation 
with radical Islam, which promises a better life for martyrs, and you can understand the growing violence in the north. [...] If you link a lack of education and attendant lack of opportunities to a high male youth population, you can imagine that some areas are actually a breeding ground for terrorism" (cit. in Rogers 2012, p. 4). Therefore, the emergence of radical groups in this region is enabled to a large extent by socioeconomic factors. For local population the recruitment by militant movement may be then an opportunity to improve its living conditions.

\section{Boko Haram - origin, ideology and strategy}

Political development in Nigeria is highly influenced by the cleavages between Christians and Muslims. The country is divided into predominantly Christian south and Islamic north. Because of the religious diversity and cleavages in Nigerian society, the 1999 constitution states explicitly in the Article 10, that "the Government of the Federation or of a State shall not adopt any religion as State Religion" (Constitution of the Federal Republic of Nigeria 1999). Nevertheless, Islamic sharia law has been introduced in the northern Nigerian states, which in some cases, such as in Kaduna State, which is half Christian, led to a violent confrontation between Muslims and Christians (Agbiboa 2013a, p. 68). Religious cleavages are closely interlinked with the ethnic factor. As it is illustrated by the case of local conflict in Jos in Plateau state between Hausa and other ethnic groups such as Afizere or Anaguta in 2008, "the battle for supremacy between Hausa and Fulani settlers and indigenes... has been largely exploited by religious bigots and political jobbers" (Ojie \& Ewhrudjakpor 2009, p. 12). Therefore, religion serves as a mobilization factor and overarching factor for deeply rooted conflict in the country.

The ideological roots and origins of Boko Haram may be traced back to the era of independence in 1960 which was followed by the rise of radical Islamist Maitatsine movement in 1970s (see e.g. Adesoji 2010). Eventually, the renaissance of Sheikh Usman dan Fodio's ideas of holy war (jihad) and advancement of conservative practice of Islam by this movement led to violent clashes between Maitatsine members and government forces in Kano in December 1980 and consequently in Maiduguri in October 1982 (Agbiboa 2013a, p. 71). Moreover, as Roman Loimeier (2012, p. 138) states, the Boko Haram movement is " $a$ result of social, political and generational dynamics within the larger field of northern Nigerian radical Islam, as represented most prominently by the Yan Izala movement". Origins of this movement date back to 1978 when it was founded by Sheikh Ismaila Idris in Jos, Plateau State, Nigeria. It is a Sufi movement which main aim is to fight everything which is considered to be a bid'a or non-Islamic elements in the northern Nigerian society. These Western influences have been brought to Nigeria to a large extent by British colonizers. During the colonial era, the British style of education, clothing and way of life were introduced. At the same time, Western education and British colonial schools supplanted traditional Islamic education and therefore, it was perceived to be an instrument of colonization and Westernization of Nigerian society (Loimeier 2012, p. 139).

The fight against non-Islamic elements within Nigerian society is enshrined also in the nickname of the organization Boko Haram. It is a combination of Hausa word Boko which means book and Arabic word Haram meaning something which is forbidden. In a broader sense, Boko Haram means 'Western education if forbidden' or 'Western education is a sin'. This name denotes inclination of this group to radical Islamic teaching which rejects most Western ideas as unIslamic (Onuoha 2014, p. 3). Nevertheless, acting leader of Boko Haram Mallam Sanni Umaru in 2009 rejected the designation 'Western Education is forbidden' and instead stated that they prefer explanation of the movement's name as "Western culture is forbidden", since "...the first gives the impression that we are opposed to formal education coming from the West... which is not true, the second affirms our belief in the supremacy of Islamic culture (not Education), for culture is broader, it includes education but not determined by Western Education" (Onuoha 2012, p. 2). However, members of this organization themselves use the Arabic 
designation 'Jamā'at Ahl as-Sunnah lid-Da'wah wa'l-Jihād' which means in English translation "Group of the People of Sunnah for Preaching and Jihad". In 2015, this organization changed its name to 'Wilāyat Gharb Ifrīqiyyah' (in English translation Islamic State West Africa Province, ISWAP) which suggests its attachment to Islamic State. The main objective of this organization is to "replace the secular Nigerian state with a regime adhering to strict Islamic sharia law, applicable throughout the entire country" (Onuoha 2014, p. 3).

Concerning organization of Boko Haram movement, until 2009 it was led by Mohammed Yusuf, who was killed during the uprising and sectarian violence in June of that year. After his death he was replaced by Abubakar Shekau, who served until then as a deputy leader of the movement. Yusuf and nowadays Shekau have served as the commanders in chief (Amir ul-Aam) of the entire movement. They have had two deputies (Na'ib Amir ul-Aam I \& II). Moreover, each state where Boko Haram operates have had its own commander or leader (amir) (Agbiboa 2013a, p. 72). Members of this movement include university lecturers, political elites, unemployed graduates and also foreign recruits. They are mostly drawn from Kanuri tribe concentrated in north eastern Nigerian states including Bauchi and Borno, and the Hausa-Fulani tribe which is prominent ethnic group in northern part of the Country (Agbiboa 2013a, p. 72). According to the analysis of CLEEN Foundation, the main motivation for recruitment of young Nigerians into this movement include "ignorance of religious teaching opposed to violence", unemployment and poverty, difficult upbringings, law level of literacy and widespread corruption (Onuoha 2014; CLEEN foundation 2014).

Ideology of the movement is inspired by deeply traditional Islamism and it is based on the rejection of all Western and anti-Islamic influences, as mentioned above. It may be illustrated, e.g. by the statement of Boko Haram's leader Mohammed Yusuf in 2009: "Our land was an Islamic state before the colonial masters turned it to a kafir (infidel) land. The current system is contrary to true Islamic beliefs" (cit. in Agbiboa 2013a, p. 73). Therefore, the idea of establishment of Islamic caliphate in the region is an important part of Boko Haram's ideology. However, it is important to stress, that Boko Haram may not be perceived and understood as a monolithic organization with unified aims and ideology. In fact, it consists of many separate factions, each of them has different strategies and objectives, from time to time competing between each other (Agbiboa 2013a, p. 75). As James Forest (2012, p. 3) suggests, there may have been a split of Boko Haram into three territorially and ethnically based factions: Kogi Boko Haram, Kanuri Boko Haram, and Hausa Fulani Boko Haram.

Currently, Boko Haram is well organized by the number of fluid cells and has developed an organized structure. It is led by about 30members advisory council (Shura) and its members are divided into specialized departments. The tactics of the movement includes suicide bombings, kidnappings, intelligence gathering, target selection and surveillance. Specialized departments also construct explosive devices, plant explosives at target sites, steal cars for use in attacks, engage security forces and recruit and train new members (Stratfor 2014).

As it comes from the Fig. 2, the Boko Haram's violent activity is concentrated mainly in the northern part of Nigeria, especially in the states of Borno, Yobe and Adamawa. However, in 2014 the attacks were carried out in a large extent also in the Kano State.

The movement's actions are based on donations from its members and from abroad. It is interlinked with other Islamist groups operating in the region, such as al-Qaeda in Islamic Maghreb (AQIM), from which Boko Haram acquires ideological as well as material and financial support. Its links to other terrorist organization, oriented to al-Qaeda, enables Boko Haram to get support from groups in Saudi Arabia and the UK as well as from Islamic organizations such as Al Muntada Trust Fund and the Islamic World Society. Moreover, in 2011, a spokesperson of the movement, Abul Qaqa admitted the direct links to al-Qaeda: "It is true that we have links with Al-Qaeda. They assist us and we 
assist them" (Vanguard 2011). However, in this respect, it is not clear whether the connection between Boko Haram and al-Qaeda is based on a practical basis, or if it is simply only rhetorical expression of support. The activities of Boko Haram are financially supported also by officials from northern Nigerian states such as governors of Kano and Bauchi States. Besides that, Boko Haram members are involved in illegal activities in the region, e.g. bank robberies or weapon trafficking from which they get materials as well as finances for movement's operations (Agbiboa 2013a, p. 74).

EVOLUTION OF BOKO HARAM SMALL ARMS VIOLENCE

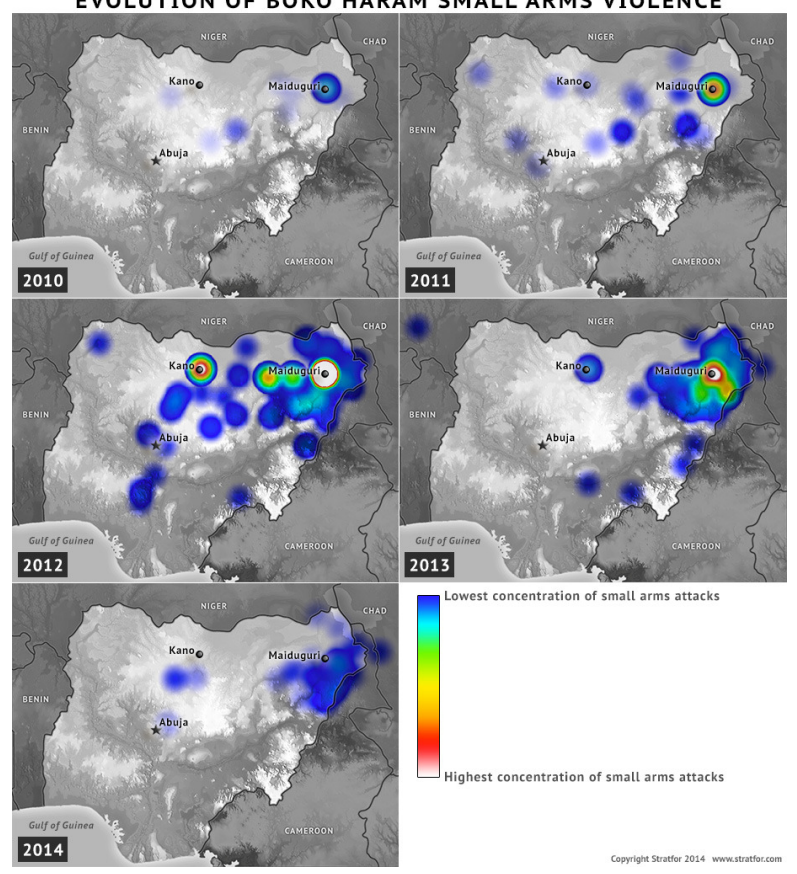

Fig. 2 - Evolution of Boko Haram Small Arms Violence (source: Stratfor 2014)

\section{Boko Haram in a wider regional perspective}

In 2009, Boko Haram became well-known for Western media when it staged an antigovernment campaign which ended with terrorist attacks that killed more than eight hundred civilians and security personnel. The uprising ended with the arrest of Boko Haram's leader, Mohammed Yusuf in June 2009. Another widely publicized incident connected to this movement is kidnapping of more than two hundred school girls in Chibok in north-east Nigeria in 2014
(Onuoha 2014, p. 2). However, nowadays, the movement is able to conduct terrorist attacks not only within the territory of Nigeria, but also neighbouring countries, for example, attacks in south eastern Niger in February 2015, suicide bombings in Chadian capital N'Djamena in July 2015 , or increasing number of suicide bombings in Cameroon at the beginning of 2016.

Transnational nature of this movement may be illustrated by the successful attraction of foreign nationals from neighbouring countries, mainly Cameroon, Chad, and Niger, caused by the charismatic teaching of Mohammed Yusuf in the early stages of its existence (Onuoha 2014, p. 3). Neighbouring Niger, Chad and Cameroon served as a safe haven for Boko Haram's fighters after its defeat and death of Mohammed Yusuf in 2009. Movement had enough space and time to reorganize and to recruit more members and to prepare for its return to Nigeria (Maiangwa 2013, p. 2). The recruitment of foreigners continued even in the later stages of the existence of this movement, for example, in 2012 it recruited number of youths in Diffa in Niger. Generally, the neighbouring states are themselves vulnerable to the terrorist attacks, since they are fragile and poor, characteristic by the low values of the Human Development Index and scarcity of economic opportunities for the young generation. Areas of these states bordering with Nigeria are part of the Lake Chad Basin and therefore exhibit very similar environmental characteristics. In this respect, environmental factors may contribute to the growth of Boko Haram not only in northern Nigeria, but also in border areas of Niger, Cameroon and Chad. Besides, Boko Haram casts Nigerien President Issoufou and Chadian President Deby as apostate Muslims and criticize them for their cooperation with the West. Therefore, the operation and existence of Boko Haram may not be perceived as solely Nigerian problem, but it is a serious regional issue. Because of that fact, Nigerian President Buhari, who won the 2015 election, is trying to cooperate on some anti-terrorist operations with neighbouring countries. In order to fight Boko Haram effectively in the whole region, he appointed a Nigerian-led MultiNational Joint Task Force which is planned to 
comprise of 8700 troops from Nigeria, Niger, Chad, Cameroon, and Benin (Thurston 2016, p. 22-23).

Transnationality of this movement may be illustrated also by its links to other radical regional and global organizations. As it has been mentioned in the previous part of this paper, Boko Haram joined Islamic State for strategic and ideological reasons in 2015. Both movements share similar ideas and have personal links to each other. As Alex Thurston (2016, p. 24) points, Boko Haram announced its affiliation to Islamic State as a response to a larger military and territorial losses. By its connection to Islamic State it then tries to prove its legitimacy and therefore, this announcement may be understood as a part of movement's propaganda. However, the affiliation is rather rhetorical then material, since it would be extremely difficult for these organizations to support each other materially due to large distance from Nigeria to Syria and Iraq.

More likely, it is possible to seek connection and similarities between Boko Haram in Nigeria and the crisis in Mali. After the coup against Malian President Amadou Toumani Toure, radical Islamic movements, namely National Movement for the Liberation of Azawad (MNLA), the Islamist Fighters of Ansar Dine, and the Movement for Oneness and Jihad in West Africa (MUJAO) with support from al-Qaeda in Islamic Maghreb gained control over significant part of Malian territory. Their common goal is the establishment of Islamic caliphate in the whole territory of Mali and introduction of ruling system based on radical interpretation of Islamic law sharia (Maiangwa 2013, p. 2). In this respect, Benjamin Maiangwa (2013) warns, that there is a considerable danger that these movements may possibly try to unite in order to fight for their gains together. This possible strong alliance of radical Islamic movements would mean worsening of not only security but also human security situation in the whole region of West Africa which has to deal with environmental issues connected with the effect of climate change (Roudier et al. 2011).

\section{Conclusion}

As it comes from the presented case study, the environmental changes may harm human security in various respects. In Nigeria, the desiccation of Lake Chad led to worsening of living conditions of local population which became more vulnerable to practices of various Islamic radical movements. Climate change and desiccation of Lake Chad itself may not be understood as a source of conflict in the area. However, worsening of living conditions, vulnerability and limited capacity of local population to adapt to new conditions create suitable environment for armed movements to emerge, since unemployed youth became more reluctant to be recruited by this organization in order to improve their living standards. Therefore, this case study supports argument that climate change itself does not produce conflict, but the lack of effective governments which are not able to deal with environmental issues may lead to conflict (e.g., Barnett \& Adger 2007; Salehyan 2008; Cook \& Bakker 2012). Boko Haram has used radical interpretation of Islam which echoed among the majority Muslim population in northern Nigeria. However, at the same time it became violent and started to terrorize local population which resulted in series of attacks and even armed uprising in 2009. Since the defeat and the death of movement's leader Mohammed Yusuf, Boko Haram has changed its strategy and focused more on the practices such as kidnapping and suicidal bombings. Nowadays, it has transnational links to similar Islamic movement in the region as well as global Islamic organizations such as al-Qaeda. However these links should be understood more in the rhetorical level. Nevertheless, Boko Haram, despite large governmental campaign, has become the most powerful Islamic radical movement in the region and is able to carry out attacks even in neighbouring countries which face the similar environmental problems in the bordering areas with Nigeria. Therefore, in order to fight it successfully, it will be necessary for Nigerian as well as for engaged international organizations to adopt a holistic strategy, including empowerment of moderate Islamic leaders and improvement of 
socio-economic and related environmental conditions in northern part of Nigeria.

\section{References}

Adesoji A (2010) The Boko Haram Uprising and Islamic Revivalism in Nigeria. Africa Spectrum 45(2): 95-108.

Adesoji A (2011) Between Maitatsine and Boko Haram: Islamic Fundamentalism and the Response of the Nigerian State. Africa Today 57(4): 98-119.

Agbiboa DE (2013a) No Retreat, No Surrender: Understanding the Religious Terrorism of Boko Haram in Nigeria. African Study Monograph 34(2): 65-84.

Agbiboa DE (2013b) Why Boko Haram Exists: The Relative Deprivation Perspective. African Conflict \& Peacebuilding Review 3(1): 144-157.

Barnett J, Adger WN (2007) Climate Change, Human Security, and Violent Conflict. Political Geography 26(6): 639-655.

Baxter P, Jack S (2008) Qualitative Case Study Methodology: Study Design and Implementation for Novice Researchers. The Qualitative Report 13(4): 544-559.

Béné $C$, Neiland A, Jolley T, Ovie $S$, Sule $O$, Ladu B, Mindjimba K, Belal E, Tiotsop F, Baba M, Dara L, Zakara A, Quensiere J (2003) Inland Fisheries, Poverty, and Rural Livelihoods in the Lake Chad Basin. Journal of Asian and African Studies 38(1): 17-51.

Burke MB, Edward M, Satyanath S, Dykema JA, Lobell DB (2009) Warming increases the risk of civil war in Africa. Proceedings of the National Academy of Sciences 106(46): 20670-20674.

CLEEN Foundation (2014) Youths, Radicalisation and Affiliation with Insurgent Groups in Northern Nigeria. Monography Series, no. 20. Accessed 26. 1. 2016. http://www.cleen.org/Youths,\%20Radicalisation\%20a nd\%20Affiliation\%20with\%20Insurgent\%20Groups\%20 in\%20Northern\%20Nigeria.pdf.

Coe MT, Foley JA (2001) Human and Natural Impacts on the Water Resources of the Lake Chad Basin. Journal of Geophysical Research 106: 3349-3356.

Constitution of the Federal Republic of Nigeria (1999) Accessed 21. 1. 2016. http://www.nigeria-law .org/ConstitutionOfTheFederalRepublicOfNigeria.htm.

Cook C, Bakker K (2012) Water security: Debating an emerging paradigm. Global Environmental Change 22: 94-102.

Forest JJF (2012) Confronting the Terrorism of Boko Haram in Nigeria. Joint Special Operations University (JSOU). The JSOU Press, Florida.
Hagmann T (2005) Confronting the Concept of Environmentally Induced Conflict. Peace, Conflict and Development no. 6 (January). Accessed 10. 2. 2016. http://www.bradford.ac.uk/social-sciences/peaceconflict-and-development/issue-6/Environmentalconflict-final-version-edited.pdf.

Homer-Dixon TF (1994) Environmental Scarcities and Violent Conflict: Evidence from Cases. International Security 19(1): 5-40.

Homer-Dixon TF, Deligiannis T (2009) Environmental Scarcities and Civil Violence. In: Günter Brauch $\mathrm{H}$ et al. (eds) Facing Global Environmental Change Environmental, Human, Energy, Food, Health and Water Security Concepts. Springer-Verlag, Berlin, Heidelberg, New York, pp. 309-323.

Loimeier R (2012) Boko Haram: The Development of a Militant Religious Movement in Nigeria. Africa Spectrum 47(2-3): 137-155. Accessed 20. 12. 2015. http://journals.sub.uni-hamburg.de/giga/afsp/article/ view/555/553

Lonergan S (1998) The Role of Environmental Degradation in Population Displacement. Environmental Change and Security Project Report 4: 5-15.

Maiangwa B (2013) West Africa's Terrorist Challenge and the Dynamics of Regional Response. Insight on Africa 5(1): 1-18. Accessed 25. 2. 2016. http://dx.doi.org/10.1177/0975087813515979

National Bureau of Statistics (2012) Social Statistics in Nigeria. Part III: Health, Employment, Public Safety, Population and Vital Registration. Accessed 15. 2. 2016. http://www.nigerianstat.gov.ng/nbslibrary /social- economic-statistics/demo-social-stat.

Ojie AE, Ewhrudjakpor C (2009) Ethnic Diversity and Public Policies in Nigeria. Anthropologist 11(1): 7-14.

Okpara UT, Stringer LC, Dougill AJ, Bila MD (2015) Conflicts about Water in Lake Chad: Are Environmental, Vulnerability and Security Issues Linked? Progress in Development Studies 15(4): 308325.

Onuoha F (2008) Environmental Degradation, Livelihood and Conflicts: A Focus on the Implications of the Diminishing Water Resources of Lake Chad for North-Eastern Nigeria. African Journal on Conflict Resolution 8(2): 35-62.

Onuoha F (2012) Boko Haram: Nigeria's Extremist Islamic Sect. Al-Jazeera Centre for Studies. February 29. Accessed 26. 1. 2016. http://studies.aljazeera.net/ ResourceGallery/media/Documents/2012/2/29/20122 29113341793734BOKO\%20HARAM\%20NIGERIAS\%20E XTREMIST\%20ISLAMIC\%20SECT.pdf. 
Onuoha F (2014) Why Do Youth Join Boko Haram? United States Institute of Peace Special Report. Accessed 23. 1. 2016. http://www.usip.org/ sites/default/files/SR348-Why_do_Youth_Join_Boko _Haram.pdf.

Rogers P (2012) Nigeria: The Generic Context of the Boko Haram Violence. Monthly Global Security Briefing, Oxford Research Group, April 30. Accessed 10. 2. 2016.

Roudier P, Sultan B, Quirion P, Berg A (2011) The impact of future climate change on West African crop yields: What does the recent literature say? Global Environmental Change 21: 1073-1083.

Salehyan I (2008) From Climate Change to Conflict? No Consensus Yet. Journal of Peace Research 45(3): 315326.

Salkida A (2012) Africa's vanishing Lake Chad. Africa Renewal, April. Accessed 15. 2. 2016. http://www.un.org/africarenewal/magazine/april2012/africa\%E2\%80\%99s-vanishing-lake-chad.

Scheffran J et al. (2012) Climate Change and Violent Conflict. Science 336: 869-871.

Seul J (1999) Ours is the Way of God: Religion, Identity and Intergroup Conflict. Journal of Peace Research 36(5): 553-569.

Slavíková L, Syrbe R U, Slavík J, Berens A (2017) Local environmental NGO roles in biodiversity governance: a Czech-German comparison. Geoscape 11(1): 1-15.

Spiess A (2005) The Role of Environmental Degradation in Population Displacement and Conflict in the Drylands of Subsaharan Africa (SSA) with Special Reference to Northern Nigeria. Sociedade \& Natureza Special Issue (May): 831-841.
Stratfor (2014) Nigeria: Examining Boko Haram. Stratfor. Global Intelligence. July 15. Accessed 26. 1. 2016. https://www.stratfor.com/analysis/nigeriaexamining-boko-haram.

Thurston A (2016) The Disease is Unbelief: Boko Haram's Religious and Political Worldview. Analysis Paper. The Brookings Project on U.S. Relations with the Islamic World, Brookings Institution. January 22. Accessed 20. 2. 2016. http://www.brookings.edu/ /media/research/files/papers/2016/01/boko-haramideology-thurston/ brookings-analysis-paper_alexthurston_final_web.pdf.

UNESCO (2012) Action Plan. Nigeria. High level International Round Table on Literacy "Reaching the 2015 Literacy Target: Delivering on the promise". September 6-7. Accessed 15. 2. 2016. http://www.unesco.org/new/fileadmin/MULTIMEDIA/ $\mathrm{HQ} / \mathrm{ED} /$ pdf/Nigeria.pdf.

Vanguard (2011) Al-Qaeda assist us and we assist them - Boko Haram spokesman. Vanguard. November 24. Accessed 20.2016. http://www.vanguardngr.com/2011/11/al-qaedaassist-us-and-we-assist-them-boko-haram-spokesman. Wolf AT, Yoffe SB, Giordano M (2003) International Waters: Identifying Basins at Risk. Water Policy 5: 2960.

Ženka J, Kofroň J (2012) Metodologie výzkumu v sociální geografii-případové studie. Ostravská univerzita. Ostrava. 